\title{
A rare cause of chronic tubulointerstitial nephritis in childhood: Questions
}

\author{
Özgür Özdemir-Şimşek ${ }^{1}$ - Gökçen Erfidan ${ }^{1} \cdot$ Seçil Arslansoyu-Çamlar ${ }^{2} \cdot$ Demet Alaygut $^{2} \cdot$ Fatma Mutlubaş $^{2}$. \\ Belde Kasap-Demir ${ }^{1,3}$
}

Received: 28 September 2021 / Revised: 29 September 2021 / Accepted: 30 September 2021 / Published online: 3 November 2021

(c) The Author(s), under exclusive licence to International Pediatric Nephrology Association 2021

Keywords Childhood $\cdot$ Chronic tubulointerstitial nephritis $\cdot$ Cresentic glomerulonephritis $\cdot \operatorname{IgE}$

\section{Case}

A 6-year-old boy was referred due to abnormal kidney function tests performed following vomiting and diarrhea lasting for 5 days before admission. The family denied a decrease in urine. There was no consanguinity between the parents nor did he have a known disease in his medical history. In his medical records, his serum creatinine was $0.6 \mathrm{mg} / \mathrm{dL} 6$ months prior to admission. He had a body weight of $21.4 \mathrm{~kg}$ (25th-50th percentile), height of $118.5 \mathrm{~cm}$ (25th-50th percentile), body temperature of $36.7{ }^{\circ} \mathrm{C}$, blood pressure of $158 / 100 \mathrm{mmHg}$ (> 95th percentile +12 ), heart rate of $104 / \mathrm{min}$, and respiratory rate of $26 / \mathrm{min}$. The patient was oriented and cooperative. In his physical examination, he had +1 pretibial pitting edema. Respiratory sounds were normal. There was no splenomegaly or hepatomegaly. Laboratory tests are shown in Table 1.

A urinary catheter was inserted, but no urine was observed. The urine output was $0.3 \mathrm{cc} / \mathrm{kg} / \mathrm{h}$ after forced diuresis. There was no finding in favor of active infection

The answers to these questions can be found at https://doi.org/10. 1007/s00467-021-05326-y

Belde Kasap-Demir

beldekasap@gmail.com

1 Department of Pediatrics, Division of Nephrology, University of Health Sciences Izmir Tepecik Training and Research Hospital, Izmir, Turkey

2 Izmır Faculty of Medicine, Department of Pediatrics, Division of Nephrology, University of Health Sciences Turkey, Izmir, Turkey

3 Department of Pediatrics, Division of Pediatric Nephrology and Rheumatology, Izmir Katip Çelebi University, Izmir, Turkey in serology including COVID-19. Kidney biopsy revealed global sclerosis in 3; cellular/fibrocellular crescents in 4; fibrous crescents in 4 ; ischemic collapse in 10-11; and segmental sclerosis in 1 glomerulus of the 43 glomeruli. Basement membranes and mesangial cellularity were normal. A mixed type of inflammatory cell infiltration with dense lymphoplasmocyte cells, containing mild-tomoderate eosinophils, was observed in the tubulointerstitial area. In addition to active tubulitis findings including loss of brush border epithelium, localized shedding of epithelial cells, tubular dilatation with proteinous hyaline casts, moderate tubular atrophy and severe interstitial fibrosis attributable to chronic tubulointerstitial nephritis (CTIN) were noted (Fig. 1a and b). In the immunofluorescence study, there was +2 fine granular IgG staining in the basement membranes, and a segmental +1 non-specific IgM staining in the basement membranes in some glomeruli. Ophthalmologic examination was normal in the patient.

\section{Questions}

1. What could be the cause of chronic tubulointerstitial nephritis in this patient?

2. Which additional tests would you perform for the diagnosis?

3. What is the most likely diagnosis in this patient? 
Fig. 1 Diffuse interstitial inflammation including a mixed type of inflammatory cells (white arrows) tubular casts (asterisks), severe tubular atrophy and interstitial fibrosis (black arrows), with immature glomeruli (empty black arrow) (a H\&E, original magnification $\times 40)$ and a cellular crescent with periglomerular fibrosis (empty white arrow) (b H\&E, original magnification $\times 100$ )

Table 1 Laboratory values of the patient at the admission
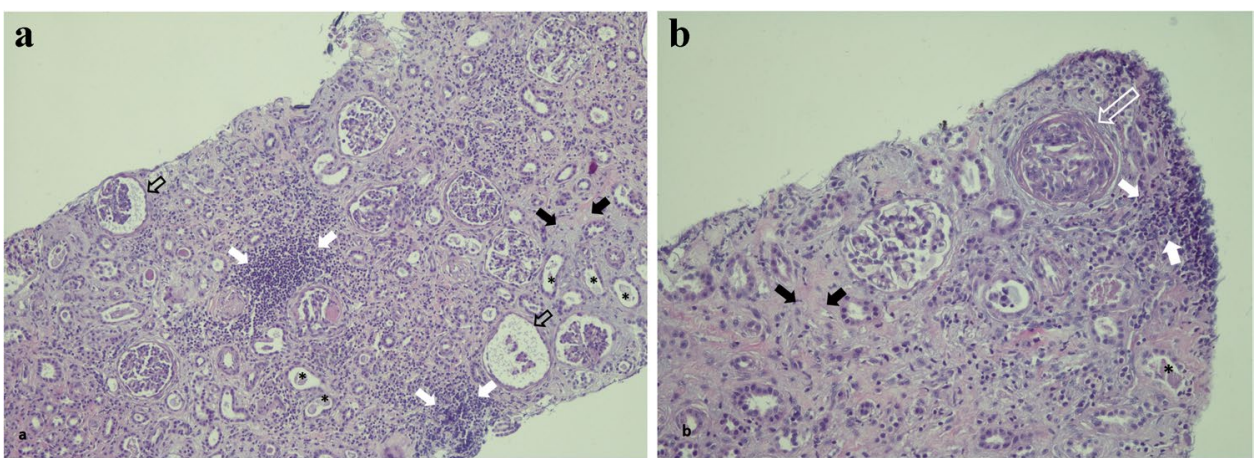

\begin{tabular}{|c|c|}
\hline $\begin{array}{l}\text { White blood cell count } \\
\text { Hemoglobin } \\
\text { Platelets }\end{array}$ & $\begin{array}{l}8.8 \times 10^{3} / \mu \mathrm{L} \\
12.4 \mathrm{~g} / \mathrm{dL} \\
356 \times 10^{3} / \mu \mathrm{L}\end{array}$ \\
\hline Serum urea & $198 \mathrm{mg} / \mathrm{dL}(N: 10-38)$ \\
\hline Creatinine & $6.2 \mathrm{mg} / \mathrm{dL}(N: 0.5-1.2)$ \\
\hline Uric acid & $6.4 \mathrm{mg} / \mathrm{dL}(N: 2-5.5)$ \\
\hline Albumin & $2.3 \mathrm{~g} / \mathrm{dL}(N: 3.5-5.5)$ \\
\hline Sodium & $130 \mathrm{mmol} / \mathrm{L}(N: 134-150)$ \\
\hline Potassium & $4.91 \mathrm{mmol} / \mathrm{L}(N: 3.5-5.5)$ \\
\hline Calcium & $7.7 \mathrm{mg} / \mathrm{dL}(N: 8.8-10.8)$ \\
\hline Phosphorus & $6.6 \mathrm{mg} / \mathrm{dL}(N: 4-7)$ \\
\hline Erythrocyte sedimentation rate (ESR) & $108 \mathrm{~mm} / \mathrm{h}(N: 0-20)$ \\
\hline Parathormone & $248 \mathrm{ng} / \mathrm{L}(N: 18.5-88)$ \\
\hline C-reactive protein & $4.6 \mathrm{mg} / \mathrm{L}(N: 0-5)$ \\
\hline Blood gass & $\mathrm{pH} 7.13, \mathrm{pCO} 248 \mathrm{mmHg}, \mathrm{HCO} 311.6 \mathrm{mmol} / \mathrm{L}$, and $\mathrm{BE}-16.7 \mathrm{mmol} / \mathrm{L}$ \\
\hline $\begin{array}{l}\text { Serum C3 } \\
\text { Serum C4 }\end{array}$ & $\begin{array}{l}1.23 \mathrm{~g} / \mathrm{L}(N: 0.9-1.8) \\
0.3 \mathrm{~g} / \mathrm{L}(N: 0.1-0.4)\end{array}$ \\
\hline $\begin{array}{l}\mathrm{IgG} \\
\mathrm{IgA} \\
\mathrm{IgM} \\
\mathrm{IgE}\end{array}$ & $\begin{array}{l}8.44 \mathrm{~g} / \mathrm{L}(N: 7-16) \\
1.75 \mathrm{~g} / \mathrm{L}(N: 0.7-4) \\
0.76 \mathrm{~g} / \mathrm{L}(N: 0.4-2.3) \\
24,600 \mathrm{IU} / \mathrm{mL}(N: 0-90)\end{array}$ \\
\hline $\begin{array}{l}\text { Rheumatoid factor } \\
\text { ANA/anti-ds DNA } \\
\text { Extractable nuclear antigen (ENA) panel } \\
\text { c-ANCA/p-ANCA } \\
\text { Anti-glomerular basement membrane antibody } \\
\text { Phospholipase-A2 receptor antibody }\end{array}$ & $\begin{array}{l}\text { Negative } \\
\text { Negative/negative } \\
\text { Negative } \\
\text { Negative/negative } \\
\text { Negative } \\
\text { Negative }\end{array}$ \\
\hline Urine analysis & Specific gravity 1018 ; glucose +2 ; protein +3 ; erythrocytes +2 \\
\hline Spot urine protein/creatinine & 24.4 \\
\hline \multicolumn{2}{|l|}{ Tubular tests } \\
\hline $\mathrm{FeNa}$ & $3.1 \%$ \\
\hline $\mathrm{FeK}$ & $172 \%$ \\
\hline TPR & $45.6 \%$ \\
\hline
\end{tabular}

\section{Declarations}

Publisher's note Springer Nature remains neutral with regard to jurisdictional claims in published maps and institutional affiliations.

\section{Conflict of interest}

The authors declare no competing interests. 